Thabiea : Journal of Natural Science Teaching
Vol. 4(1), pp. 62-81, 2021
Available online at
http://journal.iainkudus.ac.id/index.php/Thabiea
p-issn: 2580-8474, e-issn: 2655-898X

\title{
Using Comic-Based Socio-Scientific Issues in inquiry learning to increase interest and achievement in science learning
}

\author{
Ratna Lestari ${ }^{1 *}$, Tjipto Haryono ${ }^{2}$ Erman Erman $^{3}$ \\ Departement of Science Education, Faculty of Science and Mathematics, Surabaya State \\ University, Indonesia \\ 1* Correspondence: ratnalestari16070795040@mhs.unesa.ac.id
}

\begin{tabular}{|c|c|}
\hline & Abstract \\
\hline $\begin{array}{l}\text { Keywords: } \\
\text { Comic } \\
\text { SSI } \\
\text { Inquiry } \\
\text { Interest } \\
\text { Achievement }\end{array}$ & 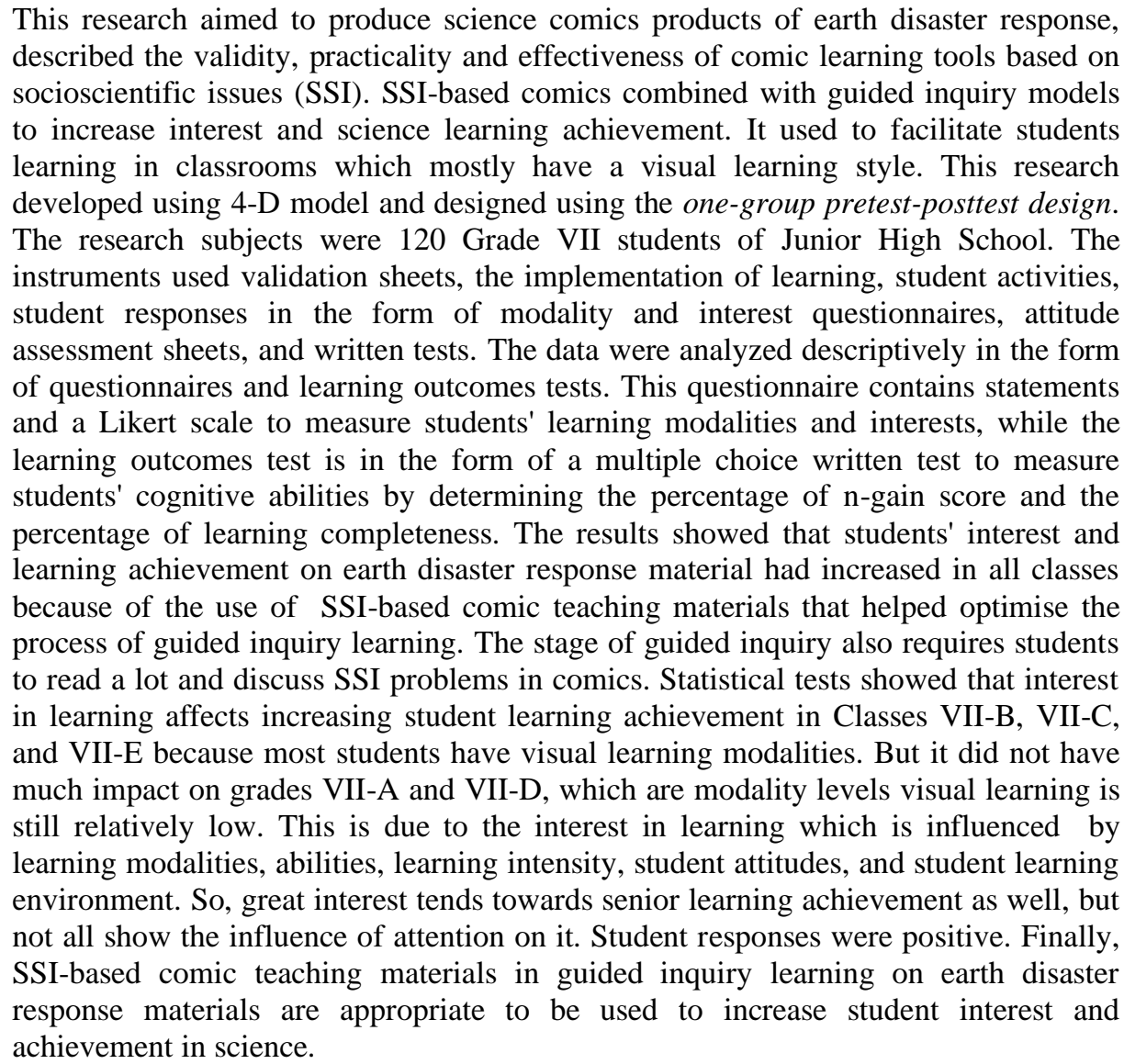 \\
\hline
\end{tabular}

To cite this article:

Lestari,R., Haryono,T., Erman, E. (2021). Using Comic-Based Socio-Scientific Issues in inquiry learning to increase interest and achievement in science learning. Thabiea : Journal of Natural Science Teaching, Vol. 4(1),62-81.

\section{Introduction}

The thinking ability of students in Indonesia is at a low level, especially students find it difficult to formulate steps to solve problems, and explain the results of their thoughts, this is due to the lack of information that students know about compiling arguments, and how to 
communicate and teachers so far in learning tend to only on the achievement of learning outcomes not on the process. This is shown by the TIMMSS 2011 study (Trends Study in Mathematics and Science Study (TIMSS 2011) showing that Indonesian students are ranked 38th in mathematics from 42 countries (Mullis et al. 2012) and PISA 2012 (the results of the 2012 PISA survey found Indonesian students in position 64 out of 65 countries in math literacy skills (OECD, 2014)(Agusman, 2017). Based on data from UNESCO (2015), Indonesian people's interest in reading is very concerning, Indonesia is stated to be in the 60th position out of 61 countries in terms of reading interest (Ayesma, Kurniawati and Ibrahim, 2020). With such a low reading interest, it will make students not interested in learning Natural Sciences. Students have low knowledge and lack of scientific literacy because their interest in learning is still low.

The many types of entertainment cause a low interest in reading and interest in learning science, games, Television (TV) shows and the internet that distract students from books. The results showed that the public is very literate to television media (Juditha, 2014). With entertainment, sports and TV shows the time that supposed to read used to play, watch TV show and explore the world of the internet. Students' low interest in reading can influence their interest in learning and change their investment in their career choices going forward. The growing interest in science becomes very important to expand engagement with science topics, careers, and hobbies (Pattison and Dierking, 2019). Most students prefer to read picture books or fairy tales rather than monotonous Natural Sciences textbooks. They do not like to read it because they think the lesson is very complex, complicated and annoying (Johnstone, 1991,Valenti et al., 2016). It reinforced by the data that $95.45 \%$ of class VII-C students learning outcomes on the earth layer material are still below the criteria for the minimum completeness score of the school that is $<75$ out of 22 students, and the questionnaire of positive responses that like to study Natural Sciences is only $45.45 \%$ of students from 22 people. It makes them less motivated to learn. Something complicated that makes them bored, uncomfortable and not eager to learn so that interest in learning down. Interest in the choice of a career in science and mathematics began to decline in junior high school both girls and boys, especially girls. It will have an impact on the lack of student knowledge of Natural Science material. The results of research by Bulunuz and Jarrett (2010) that $76 \%$ of participants who have a low interest have mediocre scientific experience compared to 58\% of participants who have high interest. Picture books are needed, and there is a dialogue that can arouse interest in learning natural science that is not boring.

These problems can overcome by developing socio-scientific issues (SSI) comic teaching materials that have many advantages that are appropriate to the characteristics of learning modalities and student interests. By using it, scientific language is transformed into a comic style that is clear, concise, and commonly used in everyday language (Dwi Waluyanto, 2005). This scientific language converted into students' everyday language and adapted to their cultural experiences so that their teaching is relevant to students. According to Johnson (2005), teachers need to put the same emphasis between scientific knowledge and the actual process of inquiry with students' language and cultural experiences. Teachers must teach science in contexts that allow students to make connections between their language and culture with scientific culture and style so that scientific content will be readily understood, more meaningful and relevant for students (Lee and Fradd, 1998, Lee, 2004). From this 
statement, it can say that science content is easier to understand if the instructor uses examples that are familiar with students, and conveys material using language that is appropriate to the student's vocabulary.

Natural Sciences is scientific knowledge that is serious, complex and complicated. Comics make it simplified into something that is more fun, easier to understand, and can earn more vivid and at the same time entertaining. This statement supported by Rota and Izquierdo (2003) that comics make complicated scientific knowledge fun and easy to understand. Comics connect knowledge with everyday events to create scientific concepts that are familiar to students (Chung et al., 2016). It also supported in other studies that children who exposed to science comics can provide scientific explanations for comics based on their own experiences (Weitkamp and Burnet, 2007). Encouraged by the curiosity of science comics in other research, children motivated to find more information in magazines, newspapers, the internet, and other sources (Rota and Izquierdo, 2003).

Comics turn abstract concepts into concrete by linking it with examples in daily life through images, symbols, and assisted by dialogue that is closely related to everyday events. Likewise, with mathematical equations that linked in everyday life will make it easier for students to understand mathematical equations as concrete lessons so that students can absorb and apply the theory to real life. Comics have something in common with science because both require unique and creative ideas that can evaluate objectively. It supported by the statement of Chung et al. (2016) that there are similarities between science and comics. Both need unique and creative ideas. Other fields such as literature and painting also require uniqueness and creativity, but only science and comics can be evaluated objectively by the community. Science and comics in the same realm are a harmonious combination.

Building a science curriculum that combines comics and allows students to read, discuss, and respond to comic content is something that unforgettable. It also cannot be overlooked that attitudes towards something will be difficult to change and tend to persist while expanding knowledge can be achieved in a short time. The consequences when we ignore the small fact, and it has implications that can alienate young students today from the science itself. And this has now also been experienced in various countries (Osborne, Simon and Collins, 2003). Though almost all aspects of human life are related to science, therefore, this issue is very urgent for immediate research.

By using comics can increase student interest, but to maintain it requires learning that is meaningful, authentic, and related to real-world situations experienced by students. Comic learning requires a Socioscientific Issue (SSI) approach that makes learning more useful because it is relevant to social issues and applies scientific knowledge to the social atmosphere in the classroom. The comic with SSI approach can overcome the low interest in reading and boredom of students, increase interest in learning, and provide conditional, exciting and meaningful learning situations for students. Comics can stimulate interest in learning, but comic learning without SSI will be challenging to maintain interest in education. It will be challenging to apply Natural Science knowledge to the social atmosphere in the classroom that makes learning less meaningful because SSI can explain problems more scientifically, foster social awareness and improve thinking skills/reasoned. SSI provides an opportunity for discussion about emerging about potential social issues for the application of science concepts, transfer processes, and social communication practices. According to 
Erman and Sari (2019), SSI will not realise if the teacher is not scientifically literate; it has implications for students who are also in the same condition. So, the teacher must change the mind or mental habits oriented to macroscopic thinking first to become more scientifically literate. This SSI-based comic learning is packed with guided inquiry models to attract inferences and produce arguments.

The weakness of the guided inquiry model without comic with SSI approach is the students' difficulties in maintaining their interest in learning, and it is difficult to move for having a more in-depth discussion of the subject matter. It is because students are not interested in the material, so learning is not optimal. The content would be interesting if it packaged in a comic form. The visual stimulation of original scientific comics not only attracts their attention and interest but at the same time, develops their memory (Saidah, 2016). Thus, the role of comics in guided inquiry is to strengthen understanding, mind, and transfer to be able to think of investigation because it opens up vast imaginations (Ambaryani and Airlanda, 2017). Comics can educate children's creativity through presenting stories that contain moral ethics and the terms of meaning that are summarised and move the sensitivity of their feelings so that it activates the brain to get closer to understanding concepts that students can digest. Inquiry helps use memory and transfer in new learning situations. The subject matter will more readily understand if it is following the interests and modalities of learning. SSI comics comply with students' interests and learning modalities. Children with visual learning modalities find it easier to understand what saw than what heard because they concentrate fully on what makes them interested and happy.

Learning with guided inquiry models without involving socio-scientific issues makes learning less meaningful because SSI comics help students understand lessons with images that sharpen memory and enhance the learning process and daily dialogue according to their language. In contrast, the SSI approach can make students understand deeper about material because it is related to social issues, as well as guided inquiry models can make students more active in learning, improve critical thinking skills and think logically. The guided inquiry requires students to read a lot (comics), so they must provide time for assimilating and accommodating the information obtained. And also provide space for students to learn according to their learning styles so that by getting new concepts balanced by resistant material long time in memory will make it easier to develop an essential idea to students. Inquiry learning helps young students who are curious about the world and find answers to problems encountered to solve problems. When they read literature (e.g. comics), students can examine the social issues they are reading and take action to overcome them in their groups, students find answers to their questions and create projects to share what they have learned. It can overcome the existence of careful learning planning. Inquiry learning without comic socio-scientific issues is unsuccessful in helping students learn and become interested in science even though science textbooks have provided. Students must read first to orient on the problem, formulate hypotheses, gather information, formulate conclusions and argue in discussions. Reading used to identify the issues and to identify problems must have a theory/knowledge about it so people must-read. Comics can make students interested in reading because, by text, people will get broad experience. Knowledge from theories can obtain if you have read. Interest in translation may not be low if using SSI comics because it can increase reading interest. By reading it, students can sharpen the memory of the concepts 
they understand, improve their imagination and creativity and foster interest in reading early on. Inquiry requires students to learn a lot.

While students are not engaging in reading, therefore, the issues in SSI need to be communicated because the contextual ones are generally still macroscopic/unclear in the contents of Natural Sciences. The point is that the SSI problem even explained in general terms of social, economic, ethical/moral so that the concept is not visible. That caused difficulties in studying Natural Sciences. With the presence of comics, they will learn it easier because comics display ideas that are not visible. It makes it easy for students to learn.

Besides weaknesses, the guided inquiry model also has advantages that are to help students master skills in cognitive processes. Students gain personal knowledge so that it can be understood and settles in their minds, arousing motivation and enthusiasm for students to study harder, providing opportunities to develop and progress according to their abilities and interests. And also strengthen and increase confidence with the process of finding self because students maximally directly involved in the process of learning activities (Farida, 2019). The inquiry model used in science learning will only succeed if it is following the experience (context) and student capacity (Erman and Sari, 2019). The success of learning using the inquiry model will have an impact on improving student learning achievement.

Comic teaching materials use a socioscientific issue approach that designed so that students can explain the problem of this natural disaster scientifically in social situations. While the guided inquiry model can help solve scientific challenges faced by students and the discussion in solving problems is more directed. Earth disaster response materials are related to social-environmental issues and can be explained in natural science studies and are controversial so that they are well suited to the characteristics of learning based on socioscientific issues. With this approach allows students to make connections between the material studied with the context of everyday social life so that knowledge can have meaning. This earth disaster material is suitable to be applied in guided inquiry learning models to increase interest in Natural Education. Sharing, giving feedback, and discussing can improve student learning and help to explain the problem of earth disasters and social-related issues in a more scientific manner (Erman and Sari, 2019).

Researchers chose the material "Earth Disaster Response" because Indonesia is one of the countries in the top ranks affected by it. And this issue is always viral on social media/society. In general, scientific problems still presented macroscopically, so students do not have a scientific lens and cannot explain the problem of natural disasters scientifically. Using visual stimulation in original comics means developing students' scientific thinking. It is an essential indicator of intelligence (Saidah, 2016).

Based on the description of the problem, a research was conducted on comics on social-scientific issues assisted by guided inquiry to increase interest and achievement in learning science.

\section{Method}

This type of research is development research that develops socioscientific issue comic teaching materials with guided inquiry models on earth disaster response materials. Procedure development using the 4D model consists of define, design, develop, and disseminate (Thiagarajan, 1974). Subjects were comic-based learning device SSI model 
guided inquiry on terrestrial disaster response material in class VII SMP Plus Al Islah Soko Tuban. Development of SSI comics on earth disaster response material which tested on students in Class VII Middle School Plus Al Ishlah Soko Tuban with a limited amount of research for 22 students in class VII-C. The next step was again widely tested in classes VIIA, VII-B, VII-D and VII-E as many as 98 students. The research design uses a one-group pretest-posttest design.

The stage of making and perfecting socio-scientific issues comics took place in 2019 at the Postgraduate Program for Science Education, State University of Surabaya. Limited trials and extensive trials were conducted from 2019 to 2020 at SMP Plus Al Islah Soko Tuban. After that, data processing and analysis were carried out.

The instruments used included validation sheets, observation sheets of learning accomplishments, observation sheets of student activities, student response sheets in the form of a learning modality questionnaire before learning and an interest questionnaire before and after learning, an attitude assessment sheet, and a written test sheet. Data analysed statistically descriptive and quantitative. Acquiring interest is measured using an interest questionnaire consisting of four indicators, namely feeling happy, caring, student involvement, and attention. The four signs include several statements that must be answered by students with a total of 27 comments. Learning achievement is measured using a written test (pretest-posttest) and then analysed using the N-Gain Score test.

\section{Results and Discussion}

The results showed that the use of comics was only effective when given to students who had a more dominant visual learning style because they understood what they saw better than what they heard. Visual stimulation will stimulate the brain to transfer information to the brain's memory and sharpen memory to foster an interest in learning. This is in accordance with the opinion of Dasar, Wurianto and Arifin (2015) that comics tend to be more suitable for children with visual learning modalities. The percentage of visual learning modalities of students in grades 7A, 7B, 7C, 7D, and 7E respectively was $69.23 \% ; 82.61 \% ; 77.27 \%$; $53.33 \%$; and $76.47 \%$. Comics teaching materials are good teaching materials because socioscientific issues comics use language that is easy to read and understand; have a clear image; has a size, cover design, content layout, shape, font size, illustration, color, image composition, paper size that is in accordance with comics in general and the format and physical form is very attractive so that it arouses students' interest in reading, studying and even wanting to own the comic. The socio-scientific issue comic products that have produced are in the form of Merapi volcano emergency response comics (comic 1); landslide and flood emergency response (comic 2); and earthquake and tsunami disaster response (comic 3). The composition of the socioscientific issue comic teaching material consists of components, namely: Cover, which is under the topic, Table of contents, Instructions for use, Introduction of characters, Auxiliary words that encourage students to formulate questions, formulate answers, gather information, and make conclusions (guided inquiry stages), The substance of earth disaster material, Summary of the evaluation, Disaster signs, Glossary, and Bibliography.

The results of comic validation based on aspects of material, design, and language 
show that the validation score of the comic exceeds the minimum score of sufficient validity $(\geq 3)$ by the validator. So, it is feasible to use. The percentage of comic validation based on material validity is $70 \%$, and the category is very valid is $30 \% .50 \%$ comic design validation with valid categories (validator 1) and $50 \%$ with very valid categories (validator 1). While validation by the second validator is $40 \%$ and the percentage is very valid at $60 \%$. The language aspect based on three validators categorised as valid by $100 \%$. Because all of them obtained a score of 4 and had reached a score of $\geq 3$, based on the assessment conducted by education practitioners, the results of the validation score on comics developed as a whole are in the correct category because it reaches $\geq 3$. Namely, the percentage categorised as valid is $63.6 \%$ and as very valid is $36.4 \%$. Then it concluded that the SSI comic learning tool with guided inquiry models on earth disaster response materials is appropriate to be used based on material/content, design, and language aspects and has met the criteria for good teaching materials.

Increasing interest and learning achievement of natural science students are not immune from the quality of learning tools. The SSI comic learning tool using the guided inquiry model is said to be of high quality because it is feasible and practically applied in learning. Feasibility measured from the results of the experts' validation of the learning tools based on the format structure, content, presentation, and language. The results of the 50\% syllabus validation are valid and $50 \%$ quite valid. The validation of the Learning Implementation Plan by three validators shows that it is feasible to use in learning. With the results of the validation of the three validators, which categorised as valid, getting a percentage of $77.8 \%$. And those classified as quite valid $22.2 \%$, then it said that it has approved for use in the learning process because already reached $75 \%$. So, it applied in learning. Based on the results the Student Worksheet, it categorised as valid at $73.7 \%$ and those valid as quite valid at $26.3 \%$.

The student worksheets that have developed are appropriate to be used in the learning process. The feasibility includes aspects of format, content, and language. The overall results of the validation score on the learning outcomes test sheet by the three validators categorised are valid because they reach a score $\geq 3$. These results indicate that the percentage classified as accurate is $33.3 \%$, and those classified as valid are 66.7\%. According to S. Akbar (2013) in terms of the content of the test results, the learning outcomes are useful because they meet the requirements. Namely, the suitability of the learning objectives, the formulation of the work instructions clarity, and the purpose of the problem clarity that has done. From the aspect of the language test the mastery of the concept is good because it meets the requirements (Juditha, 2014), namely: the suitability of the language used with the rules of the Indonesian language, the sentence does not contain a double meaning, the communicative problem sentences formulation. Based on the results of the reliability analysis obtained with the value of $\mathrm{r}_{11}=0.675$. While the calculation from the table got the $\mathrm{r}_{-}$tabel $=0.423$ at the alpha significance level $=0.05$ or $95 \%$ confidence level, the $r$ count is higher than $r$ table. Then all item items are declared to be reliable in the top category. The calculation results show constant (steady), which allows an honest comparison and guarantees consistency. So, the test questions made already meet the requirements based on these criteria and are suitable for use in learning. Also, the effectiveness measured from the completeness of the indicator questions results. It showed overall integrity because more than $75 \%$ of students have reached the 
integrity of the indicators. The overall results of the validation score on the questionnaire interest in learning by the three validators categorised validly because it achieved a score $\geq$ of 3. These results indicate that the percentage classified as quite valid is $33.3 \%$, and valid are $66.7 \%$. It happens because the questionnaire made by interest is under the indicators of it that is the feeling of pleasure, attention, student involvement, and a sense of enthusiasm. It outlined the criteria for each assessment tests and the questionnaire made to adjust its. So, the results are declared valid, so it is suitable for use in learning.

Increased student interest in learning can occur due to socio-scientific issue-based comic learning tools with guided inquiry models that are otherwise practically used in education. The practicality of knowledge saw from the results of the implementation and the consequences of student activities. Overall, it has carried out well. It does not escape the role of the teacher and students, so good knowledge tends to show good student activity. The student learning interest increases because supported by the implementation in the plan has been carried out $100 \%$ in limited tests, and each stage of guided inquiry in the average area test Class has reached a minimum percentage of $\geq 61 \%$, which is categorised well. It also happens because there is a match between teacher activities and student activities, which are also $100 \%$ implemented. Although there are percentage differences at the level of the category, in general, it has executed well. It also influenced by the many opportunities for students to learn and be actively involved. So, proper implementation and activities show that SSI-based comic learning with guided inquiry models has carried out effectively.

Learning Implementation Plan at the problem orientation stage in learning in Classes $7 \mathrm{~A}, 7 \mathrm{~B}, 7 \mathrm{C}, 7 \mathrm{D}$, and $7 \mathrm{E}$ has a percentage of $\geq 61 \%$, namely $81 \%, 83 \%, 94 \%, 88 \%$, and $81 \%$. Each category is excellent. At this stage, it did by giving a brief introduction and video shows and pictures in the comics-related to the material/problem to focus and focus students' minds towards the problem formulation. The teacher gives apperception by linking the material to be studied with the previous content (student experience) and relevant to daily life, as well as reminding the prerequisite material by asking questions. It supported by Johnson's opinion that contextual learning allows students to connect the contents of the article with the context of everyday life so that it is more meaningful than previously. It reinforced by the theory of D. et al. (1979) that intellectuals develop when someone faces new and challenging ideas and relates these ideas to what they already know. Also, the teacher motivates by showing videos related to comic stories in full and shows the pictures about the phenomena of the Earth's layers to stimulate students to ask questions. It adjusted to the interests of students in the form of the image shows about natural events that have presented in comics. According to information processing theory (Accounting Principle Teacher's Effective Teaching Practices Based on Slavin's Model)', 2020), pictures will help a person to experience the process of repetition or coding to be stored in long-term memory so that it helps to recall what learned. This motivating phase gave to attract students' attention to the material, and the teacher provides special attention.

It reinforced by Cheung (2018) that teachers must pay special attention to the relationship between academic self-concepts and interests if they want to motivate students to study science at school. The next preliminary stage is to convey the learning objectives sequentially with a brief and clear direction that leads students to problem orientation. Learning objectives need to express so that students are focused on what they will learn and 
can ensure that it is useful for them later. The delivery implementation is inseparable from the attention and understanding of students about the goals. As said by Ahmadi, Arief and Wibowo (2021), students' understanding of learning goals can foster interest in learning, thereby increasing motivation. Then, the teacher displays an outline of power points about the layers of the Earth in a short and precise manner covering all segments of the Earth's constituents to orient students on the problem. Like the guided inquiry model at the beginning of learning (the introduction/phase 2: formulating the problem), the teacher gives a problem or phenomenon to be solved by students. Then, students are encouraged to ask questions and think/ reason to analyse the issues or challenges presented by the teacher about the phenomena that occur in the Earth's layers.

At the stage of formulating questions / problems, the percentage gets $\geq 61 \%$, namely $88 \%, 91 \%, 91 \%, 91 \%$ and $91 \%$ with very good categories. The teacher provokes students to ask questions to encourage students to think and ask questions and direct their attention to aspects that are not yet known. In the opinion of Haris (2012), asking is one of the entrances to gain knowledge. Because asking questions in learning activities can encourage and guide students in thinking, which is the most important part of guided inquiry learning that is digging up information, confirming what is already known, and directing the attention to unknown aspects. The opinion supported by a statement from Pudjiadi (2005), the benefits of raising a problem at the beginning of learning (the introduction), can trigger pros and cons so that students need to think and analyse the issue. It is reinforced by Oberg and Daniels (2013) opinion that inquiry learning begins with building questions, gathering information sources, and ending with answers/conclusions. The learning process involves students and teachers only as a guide and facilitator in learning. The teacher acts as scaffolding.

The next stage (phase 3: proposing a hypothesis / making a short answer) is the teacher asking students to make a hypothesis (short answer) on the formulation of the problem they have written. The stages of making temporary answers (percentage of performance) in Classes 7A, 7B, 7C, 7D, and 7E each get a percentage of 75\% (good), 81\% (very good), 81\% (very good), $75 \%$ (good), and $88 \%$ (very good). It happens because most groups in each class have been able to formulate hypotheses/short answers logically and correctly. Also, students can determine the best interpretation through group discussion and write. Then for right belief in the worksheet even though there is still one hypothesis/answer that is not correct, the lowest percentage of performance and learning activities achieved by classes VII-A and VIID. Because of the students still have difficulty making short answers. Students still have this difficulty because their abilities are relatively low and do not follow the training given by the teacher before.

Phase 4: gathering information each class gets a percentage of $75 \%$ (7A), $88 \%$ (7B), 97\% (7C), 78\% (7D), and 81\% (7E) with successive categories are good, very good, very good, good, and very good. The results of the assessment in this phase carried out with a very good average. Students conduct group discussions where students exchange ideas with peers and smarter children or children who are better able to teach less intelligent children. Apart from training students in thinking, they can also practice collaboration and socialisation among peers. This statement is in line with Vygotsky's theory which emphasises the nature of social learning in learning that students learn through interaction with adults or peers who are 
more capable (Accounting Principle Teacher's Effective Teaching Practices Based on Slavin's Model)', 2020).

In phase 5: the stage of formulating a conclusion gets a percentage of $7 \mathrm{~A}$ implementation at 75\% (good), 7B 75\% (good), 7C gets 97\% (very good), 7D at 75\% (good), and $7 \mathrm{E}$ at $81 \%$ (very good) ). Grades $7 \mathrm{~A}, 7 \mathrm{~B}$, and 7D get the lowest percentage in making conclusions $(75 \%)$ because there are still groups that when concluding the discussion results are rather long (6-10 minutes) even though the conclusions are true / near true. The teacher concludes learning from beginning to end clearly but lack of affirmation/repetition despite involving students to argue until an agreement reached conclusions (students who respond $40 \leq \mathrm{x}<70 \%$ ). In the case of Devi's group, he was unable to make conclusions about the phenomenon of hail, flash floods, and earthquakes related to the structure of the Earth's layers. This group is not able to explain scientifically. The explanation is still macroscopic. It showed that students are not scientifically literate about science problems in society. According to Vygotsky's theory that intellectuals develop when someone faces new and challenging ideas and linking these ideas with what they know, and interactions with others can enrich intellectual development. The teacher's leading role is to act as a helper and mediator in learning (Nur, 2008). It showed that the activities of formulating conclusions have been carried out well but not maximal.

In the last stage (phase 6): reflecting shows the percentage of each class is $75 \%$ (good), 84\% (very good), 84\% (very good), 78\% (good), and 78\% (good). Reflection is a learning activity in the form of student assessment or feedback on the teacher after participating in a series of teaching and learning processes within a certain period. Reflection can do by giving questions to students. The smoothness of this activity cannot separate from students; understanding of what they have just learned. The opinion of Haris (2012) that reflection can make students practice how to think about what they have just learned or to think back about what they have learned in the past. This activity is to evaluate old knowledge or experience with new knowledge or experience. In cognitive theory, students settle what has learned as a new knowledge structure as well as enrichment or revision of old knowledge. So, the reflection activities carried out were going well.

Percentage of activities per class, on average, $\geq 61 \%$ are categorised as very good. In comparison, the lowest (69\%) occurs in class 7A, namely: (1) formulate a short answer, still two/three incorrect hypotheses, and guidance from the teacher at the second meeting; (2) formulating conclusions (72\%) because students still need help from the teacher at the second meeting. Class 7B is the lowest percentage when the activity expresses (75\%) because the discussion results are quite long for the correct outcomes. The teacher lacks affirmation when finding with students. In class 7D the activity that has the lowest percentage $(75 \%)$ is the activity of making short answers because there is still one incorrect hypothesis, gathering information. After all, even though collecting data from various sources skillfully but still need guidance from the teacher and in gathering information applying $4 \mathrm{M}$, formulating conclusions. After all, students conclude the results of the discussion for a long time, but the findings are still correct and reflect because there are still some students who are not responding. Then in class $7 \mathrm{E}$, which gets the lowest percentage in the activity of formulating conclusions $(75 \%)$ because it takes a long time to be able to conclude correctly. The action of 
making provisional conjectures requires experience and much knowledge that students must possess in finding answers from the results of their analysis. In learning, students must be active, and the teacher is only a facilitator, suitability of student activities with teacher activities to produce excellent and enthusiastic knowledge.

The percentage of interest in learning Natural Sciences based on interest before and after learning comic socio-scientific issues with the guided inquiry model of each class has increased in percentage that showed in figure 1 . There is an increase in the percentage of interest in learning in all classes. It showed both from the indicators of pleasure, attention, involvement, and student interest in the Study of Natural Sciences.

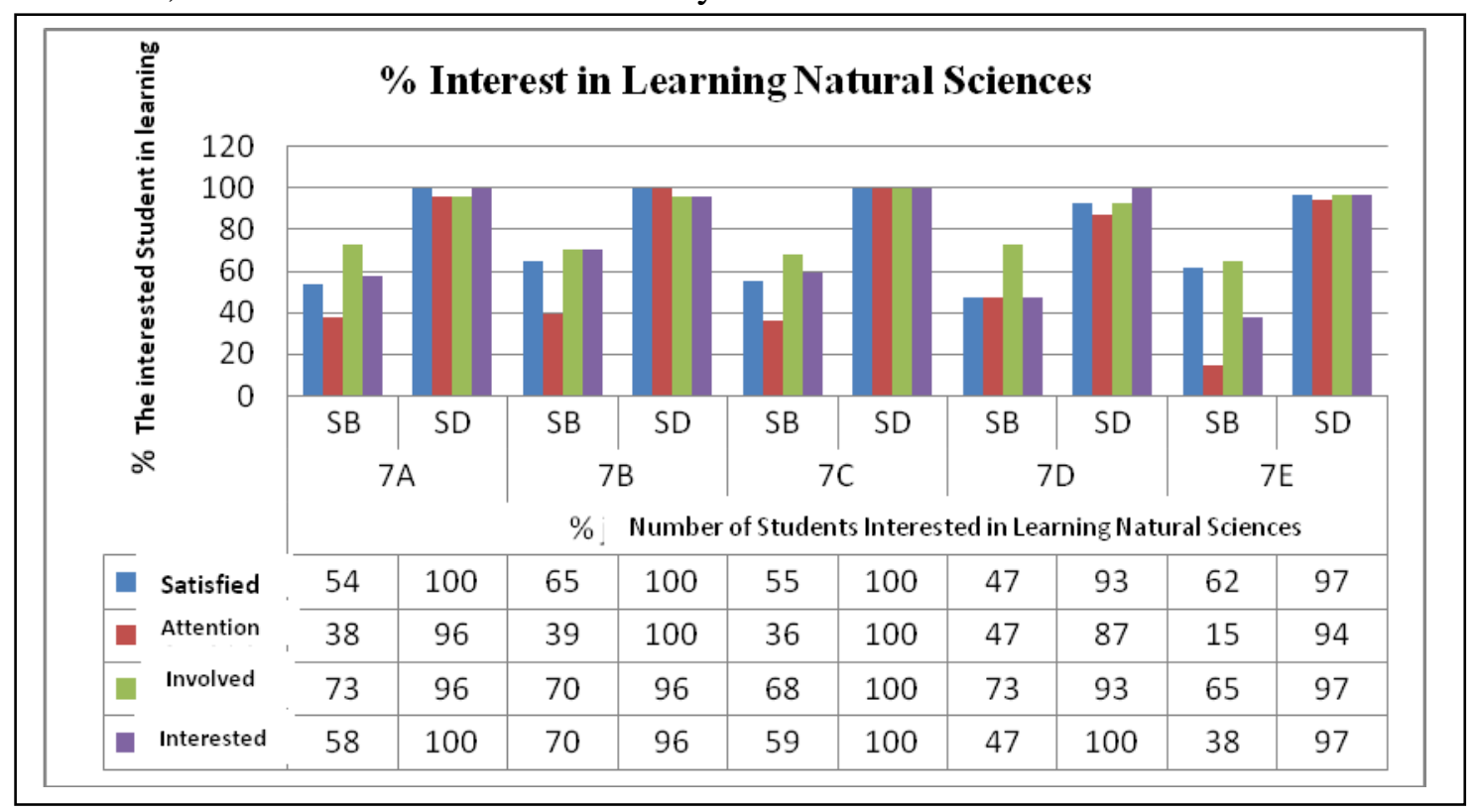

Figure 1. \% Interest in Learning Natural Sciences

*SB: before applying SSI-based comics in guided inquiry learning

*SD: after applying SSI-based comics in guided inquiry learning

The low interest in learning science can overcome by implementing comic-based scientific-based learning issues using the guided inquiry model. Increased learning the importance of students in Class VII-C after participating in SSI comic learning using guided inquiry models showed that $45 \%$ of students who initially did not like science. The $55 \%$ liked science $(41 \%$ were quite satisfied $+14 \%$ satisfied). After experienced by new method a percentage increase to $100 \%$ happy with science $(23 \%$ very satisfied $+73 \%$ satisfied $+4 \%$ quite satisfied). In extensive trials, the highest percentage increase in the happy aspect occurred in Class VII-A and VII-D by $46 \%$ and the lowest in Class VII-B and VII-E by 35\%. The increase in the percentage of students' interest in learning towards science is due to the teaching material developed under the learning modality of students who like comics. If students already like comics, then they will be interested in reading them so that their learning becomes meaningful because it did without coercion. Students become happy with the Natural Sciences because the material packaged in the form of comics / illustrated stories that are entertaining and can align with various other types of entertainment such as film, television, video animation, and cinema (Dwi Waluyanto, 2005). Comic books in the form of illustrated storylines combined with daily conversation dialogues that make students not 
bored and feel happy when reading them. Comics can convey information in a simplified, easy to understand, easily absorbed, and secure way to follow and remember so that it can send information effectively and efficiently. The happy attitude of students can saw from the look on their faces who look excited when taking lessons, which initially seemed lazy to move/learn to look happy when learning and without being told to, and they are aware of the many uses of studying Natural Sciences.

Interest in learning Class VII-C in the limited test aspect of attention shows an increase in the percentage of $64 \%$ of students lacking focus and the remaining $36 \%$ enough attention to increase to $100 \%$ of students giving attention to learning (14\% very $+4 \%$ enough $+82 \%$ attention). In the extensive test, the percentage increase in the focus was highest in class VII-E $79 \%$ and lowest in class VII-D by $40 \%$. The increase in the percentage and intensity of students' attention increases because students feel happy and interested in the subject matter. It happens because the teacher motivates students by presenting pictures in comics. And they were showing videos related to the phenomena of the layers of the Earth as well as convincing students the importance of the material to be learned, opening the lesson by providing concrete examples that link the subject matter to the cultural background of students in a way effective. It did arouse students; curiosity to increase their intrinsic interest in learning the material. The attention of students appears from the students; efforts always to listen and pay attention to the teacher explanation, actively listening and discussing, not busy or talking to themselves, and paying attention to the assignments given by the teacher. One way that teachers can do is following the statement of Basuki (2014) that to attract interest and increase student learning retention; teachers must encourage students to connect new knowledge with the cognitive structure/experience they already have. Based on information processing theory states that working memory or memory can work and be able to capture information if the information is given attention (attention) by individuals (students). The role of perception influences this attention so that information can survive in working memory. What must do is to strive for the amount of information not to exceed the capacity of working memory and to repeat information gradually and continuously.

The next indicator of interest in learning is exciting. The percentage of interest of students in Class VII-C (limited trials) towards Natural Sciences has increased from $41 \%$ of students less interested, and the remaining $60 \%$ have engaged in rising to $100 \%$ involved in being $55 \%$ very interested and $45 \%$ interested. While extensive trial data shows the highest percentage increase in the aspect of interest that occurred in Class VII-E rose by $59 \%$ and the lowest percentage increase in class VII-B rose $26 \%$. Interest can see in the expression of curiosity relevant to science, often asking questions, always doing the task and never delay, and still curious and impatient to want to follow the next learning. The way to measure and foster interest in science is to understand how students' express curiosity about the nature of an object, phenomenon, or topic given (Megan \& Sherry, 2014). It found that students with different expressions of curiosity would show their interest in science differently. The high level of curiosity will make students have continually renewable worlds of knowledge that are challenging and interesting for them to learn more. It prepares students more sensitive to natural phenomena around so that more things will learn. And provide new surprises for students in learning many things. Students who filled with curiosity will be happy and have a high desire to learn it. After they feel satisfied with their interest, later, students will realise 
how fun the learning activities carried out. Teachers must able to open students' minds about new things, give students an understanding, provide lots of leeways to ask questions, teach new ideas to a study, and tries to find something they have never known. The teacher must always instil in students to realise that learning is something fun and can accustom students to read various types of readings to explore their knowledge. It related to Piaget curiosity can motivate them to build images in their minds about the environment actively they live in (Slavin, 2011).

Based on data (limited trial) states that the learning interest of Class VII-C students initially, only $68 \%$ of students involved and $32 \%$ less been actively engaged in learning. Then after participating in SSI comic learning using guided inquiry models experienced, it found an increase in interest to $100 \%$ of students involved in learning. In comparison, extensive trial data showed the highest percentage increase in the aspect of student involvement occurred in Class VII-C, and VII-E increased by $32 \%$ and the lowest percentage increase achieved by Class VII-D by $20 \%$ (see figure1). The percentage of involvement has increased because students showed progress in participating and were more active in learning. Student involvement appears from the awareness of learning science without being told to actively discussing and responding to the presentations of other groups, always giving input or opinions in the group, and still involved in every learning activity. Student involvement can also saw in student activities.

Students who are not scientifically literate about science issues and have not been able to understand social-scientific issues (SSI) in the community handled with SSI. SSI supports the development of scientific literacy knowledge through the integration of social-scientific issues (Zeidler, Herman and Sadler, 2019). SSI has a scientific basis and considered socially crucial because it raises various political, economic, and ethical questions (Ratcliffe and Grace, 2003). SSI integration has the potential to provide extensive opportunities to study and evaluate information scientifically and critically. SSI can only be understood if students can identify, define, describe, and explain science problems explicitly and implicitly. Sharing, giving feedback, and discussing enhance learning and help solve issues scientifically (Erman and Sari, 2019). However, understanding science with different contexts is not easy because it requires the ability to change from one setting to another, and comics can help students understand science problems more efficiently. Comics help stimulates student interest in science issues and promotes science literacy (Olson, 2008). It supported in other studies that children who exposed to science comics can provide scientific explanations for comics based on their own experiences or prior experiences (Weitkamp and Burnet, 2007).

Students interest in learning can saw from their attitude towards science. Based on the observation analysis result of student attitudes showed a positive attitude with a percentage of $100 \%$ even though each attitude indicator showed a different percentage in each category. The positive attitude influenced by many factors, mainly because of the environment. It supported by Mulyasa's opinion that a less conducive environment will hinder the formation of students'spiritual and social attitudes. It means building religious beliefs, and social attitudes need to be supported by a favourable environment both physical and non-physical environment because the environment is safe, comfortable, clean, orderly, far from commotion or criminal action. Activities that are focused on students can arouse their enthusiasm and enthusiasm for learning. Based on attitude assessment data, it can saw that 
students show a positive attitude towards learning comics based on socioscientific issues with guided inquiry models on earth disaster response materials. From this positive attitude will make students interested in learning Natural Sciences, more easily motivated and more comfortable to absorb/precipitate the material taught. The approach of students who categorised as useful also shows that students feel comfortable and like the learning process conducted by the teacher. It reinforced by the opinion of Haris (2012) that in general, the attitudes that need to assess are: 1) positive attitude of students towards the subject matter. With a positive attitude in students will grow and develop their learning interest in science, will be easier to be motivated, and will more easily absorb the subject matter; 2) A positive attitude towards the teacher. If students do not have a positive attitude towards the teacher, they will tend to ignore the things taught. It is difficult to absorb the subject matter shown; 3) A positive attitude towards the learning process also needed. So that the learning process is exciting, comfortable, and enjoyable, it can foster interest and motivate students to achieve maximum learning outcomes; and 4) Attitudes related to values or norms related to a subject matter. Students' perception of Natural Sciences changes to be more favourable for increasing their interest in learning it.

Each class was declared complete with a first category, and there was an increase in learning outcomes in all classes. Despite the rise in the pretest to posttest, there were still students who showed less effect on the results of the N-gain score test. The percentage of students' mastery learning in each class in a row namely class 7A (92\%), 7B (96\%), 7C (100\%), 7D (93\%), and grade 7E (91\%) were declared complete because they had reached the KKM School namely 75 . Normalised gain ( $\mathrm{N}$-gain score) aims to determine the effectiveness of using a method in research. $\mathrm{N}$-gain score test used when there is a significant difference between the average pretest and posttest values through the paired sample t-test.

Refer to the value of $\mathrm{N}$-gain in the form of a percent (\%) and descriptive output, the $\mathrm{N}$-gain Score test results obtained for each class presented in Table 4.1 below.

Table 1. N-Gain Score Test

\begin{tabular}{|c|c|c|c|c|c|c|c|c|c|c|}
\hline \multirow[t]{2}{*}{ N-gain Score category } & \multicolumn{2}{|c|}{$7 \mathrm{~A}$} & \multicolumn{2}{|c|}{$7 \mathrm{~B}$} & \multicolumn{2}{|c|}{$7 \mathrm{C}$} & \multicolumn{2}{|c|}{ 7D } & \multicolumn{2}{|c|}{$7 \mathrm{E}$} \\
\hline & $\mathrm{N}$ & $\%$ & $\mathrm{~N}$ & $\%$ & $\mathrm{~N}$ & $\%$ & $\mathrm{~N}$ & $\%$ & $\mathrm{~N}$ & $\%$ \\
\hline High & 18 & 69,2 & 12 & 52,2 & 8 & 36,4 & 4 & 26,7 & 13 & 38,2 \\
\hline Moderate & 8 & 30,8 & 11 & 47,8 & 14 & 63,6 & 9 & 60 & 21 & 61,8 \\
\hline Low & 0 & 0 & 0 & 0 & 0 & 0 & 2 & 13,3 & 0 & 0 \\
\hline \multirow[t]{2}{*}{ N-gain category $(\%)$} & \multicolumn{2}{|c|}{$7 \mathrm{~A}$} & \multicolumn{2}{|c|}{$7 \mathrm{~B}$} & \multicolumn{2}{|c|}{$7 \mathrm{C}$} & \multicolumn{2}{|c|}{$7 \mathrm{D}$} & \multicolumn{2}{|c|}{$7 \mathrm{E}$} \\
\hline & $\mathrm{N}$ & $\%$ & $\mathrm{~N}$ & $\%$ & $\mathrm{~N}$ & $\%$ & $\mathrm{~N}$ & $\%$ & $\mathrm{~N}$ & $\%$ \\
\hline Effective & 7 & 26,9 & 6 & 26,1 & 4 & 18,2 & 4 & 26,7 & 8 & 23,5 \\
\hline Effective enough & 19 & 73,1 & 17 & 73,9 & 12 & 54,5 & 8 & 53,3 & 22 & 64,7 \\
\hline Less effective & 0 & 0 & 0 & 0 & 6 & 27,3 & 2 & 13,3 & 4 & 11,8 \\
\hline Tidak Efektif & 0 & 0 & 0 & 0 & 0 & 0 & 1 & 6,67 & 0 & 0 \\
\hline
\end{tabular}

High learning interest enables students to achieve maximum learning outcomes. Increased interest in learning tends to have an impact on improving the results of the pretest to posttest. The data shows that the average value of the initial test before learning SSI comics by 55.68 and after the SSI comics determining the average value of the test increased to 84.52. 
Table 2. Statistic of Try out 2 (large number of participants)

\begin{tabular}{ccccccc}
\hline Groups & Mean & Sd & Min & Max & t-test & $\begin{array}{c}\text { Sig. (2- } \\
\text { tailed) }\end{array}$ \\
\hline $7 \mathrm{~A}(\mathrm{~N}=26)$ & $-50,723$ & 6,632 & $-53,401$ & $-48,044$ & $-39,001$ &, 000 \\
\hline $7 \mathrm{~B}(\mathrm{~N}=23)$ & $-45,350$ & 10,898 & $-50,063$ & $-40,637$ & $-19,956$ &, 000 \\
\hline $7 \mathrm{C}(\mathrm{N}=22)$ & $-28,773$ & 10,610 & $-33,477$ & $-24,069$ & $-12,720$ &, 000 \\
\hline $7 \mathrm{D}(\mathrm{N}=15)$ & $-41,249$ & 15,987 & $-50,102$ & $-32,395$ & $-9,993$ &, 000 \\
\hline $7 \mathrm{E}(\mathrm{N}=34)$ & $-43,747$ & 10,854 & $-47,535$ & $-39,960$ & $-23,501$ &, 000 \\
\hline
\end{tabular}

Table 2 above shows whether there are differences in the pretest and posttest. Significance value of 0,000 so that the significance value is less than 0.05 then there is a significant difference between learning outcomes in the pretest and posttest. The conclusion is that there are significant differences between the learning outcomes of science in the pretest and posttest data, so that from these results it can be said that through comic learning using guided inquiry models can improve students' science learning outcomes.

Table 3. Statistical Data Effect of Interest in Learning Against Learning Outcomes

\begin{tabular}{|c|c|c|c|}
\hline Groups & & $\mathbf{T}$ & Sig. \\
\hline $7 \mathrm{~A}(\mathrm{~N}=26)$ & \multirow{5}{*}{$\begin{array}{c}\text { Interest to } \\
\text { learn }\end{array}$} & 1,070 & .296 \\
\hline $7 \mathrm{~B}(\mathrm{~N}=23)$ & & 2,609 & .017 \\
\hline $7 \mathrm{C}(\mathrm{N}=22)$ & & 6,620 & .000 \\
\hline $7 \mathrm{D}(\mathrm{N}=15)$ & & 0,698 & .498 \\
\hline $7 \mathrm{E}(\mathrm{N}=34)$ & & 3,434 & .002 \\
\hline
\end{tabular}

Increased interest in learning does not necessarily affect student learning outcomes. Based on the results of the t-test namely the influence of learning interest on learning achievement in Class 7B (Sig.0,017<0,05; $t_{\text {count }} 2,609>t_{\text {tabel }} 2,086$ ), 7C (Sig. 0,000<0,05; $t_{\text {count }}$ 6,620 $>t_{\text {tabel }} 2,093$ ), and 7E (Sig.0,002<0,05; $t_{\text {count }} 3,434>t_{\text {tabel }} 2,040$ ) in Female class, but not in Class 7A (Sig.0,296>0,05; $\mathrm{t}_{\text {count }} 1,070<\mathrm{t}_{\text {tabel }} 2,066$ ) and 7D ( Sig.0,498>0,05; $\mathrm{t}_{\text {count }} 0,698<$ $\left.t_{\text {tabel }} 2,176\right)$ In the Male class that does not show the influence of learning interest on student achievement. It is influenced by visual learning modalities that are still low in men's classes, student's capacity/ability, and time management in learning. Male students are less able to manage learning time by playing time compared to female students. Therefore, high learning interest does not necessarily make learning achievement also high. However, the data shows that most students with low learning interest will tend to have low learning outcomes and vice versa, even though two classes do not significantly affect learning achievement. In general, high learning interest will affect learning outcomes which tend to be high too because someone will make more effort if someone has high learning interest. Its interest in learning is influenced by the modality/learning style of students. Students show the effect of their interest on achievement if they have a visual learning modality that is more dominant than other learning modalities. In this case there is an increase in student learning outcomes. It can 
saw in the results of the percentage of student analysis in each class in the research method, namely Class VII-A and VII-D, there are still many students who have a learning modality other than visual, which is almost half a percent. The observations show that students who learn by using a dominant learning style while taking a test will achieve significantly higher grades than those who study in ways that are not in line with their learning styles. According to Alexander, Johnson and Kelley (2012) that males receive the same level of scientific opportunities without regard to their interests. This opinion is supported by Dasar, Wurianto and Arifin (2015) who says that comics tend to be more suitable for children with visual learning modalities.

Experience, ability, attitude, and interest in learning affect learning outcomes. Differences in student learning outcomes in Class VII-A, VII-B, VII-C, VII-D and VII-E are influenced by the main factors, namely interest in learning and students' attitudes towards science. Students' attitudes towards science and the many factors of influence such as gender, teachers, curricula, cultural and the quality of teaching (Osborne, Simon and Collins, 2003). This data is in line with the opinion of Musfiqon (2012) that learning outcomes are influenced by factors from within students (internal factors), especially those concerning students' abilities, motivation, interests, attention, attitudes, study habits, perseverance, socio-economic conditions, and psychological. Meanwhile, environmental factors (external factors) also affect student learning outcomes. The quality of teaching also referred to teacher's competence which includes the teacher's ability to teach, mastery of the material, and the teacher's attitude towards the subject and according to his statement that $70 \%$ of student learning outcomes influenced by student ability and $30 \%$ controlled by the environment. It shows that the factor from within students is a considerable influence and a more dominant influence on learning outcomes to be achieved.

Improved learning achievement is also due to the influence of the use of teaching materials that are appropriate to the child's learning modality and the child's age. According to Keogh and Naylor (1999) states that teaching materials with a cartoon concept can motivate learning groups with all different age ranges and backgrounds, including children who are emotional and challenging to adapt. According to Piaget that junior high school-age children are in the development stage of the stage of formal operation (11-15 years) which is marked by the achievement of the formation of a child's cognitive structure at the highest level of development and can think logically in solving various problems. Children already can apply theories and hypotheses to solve problems. The stage also marked by the ability to reason scientifically by building hypotheses and trying to test hypotheses and the development of higher-order thinking skills. The first time a child can operationalise the ability to reason logically under the context of the problem at hand. The formal thinking stage also characterised by the ability to construct and the ability to understand the content/meaning of a problem. If the child can think formally, the child has passed the stage of concrete thinking (Surna, I. Nyoman \& Pandeirot, 2014). This way of thinking is suitable to be applied using guided inquiry models, and SSI comics can provide imaginative visual stimulation and as a means of developing scientific thinking in children as an essential indicator for intelligence and the development of thought patterns. This visual stimulation not only attracts the attention and interest of the child but also develops his memory because it is by the modality/learning style of the visual child (Saidah, 2016). 
Improved learning outcomes also caused by the learning process effectiveness. It much influenced by the quality of observation and attention given by students. Observation/perception is a form of cognitive behaviour that is a process of recognising the environment using the senses. The senses receive stimuli to be transmitted to the brain (sending information) then giving meaning/interpretation to the stimuli received. The effectiveness of observations depends on stimulation factors, self factors, and the surrounding environment. The stronger the learning stimuli provided, the more influence the effectiveness of one's observations. The better the quality of one's senses and the more conducive learning environment will significantly affect the effectiveness of one's comments.

Improving learning achievement is also not independent of individual learning completeness and the indicator completeness matter. Own integrity measures how successful students are in learning, while completeness indicators indicate how successful the teacher is in teaching. Students said to be complete if they have a minimum cognitive learning value of 75. Class VII-C student learning outcomes (limited test) reported being $100 \%$ complete overall in the posttest even though there are two children whose grades are 75 the same as Minimal Completeness Criteria. Still, student learning outcomes show an increase in categories quite significant from the previous pretest scores whereas in the extensive test in Classes VII-A, VII-B, VII-D, and VII-E the completeness of learning outcomes was $92 \%$, $96 \%, 93 \%$, and $91 \%$, respectively. It showed that the developed teaching material is effectively used in junior high schools because the percentage of students who complete it reaches $61 \%$. It does not escape the careful preparation of the teacher, observers, and students before learning. Overall indicator completeness has exceeded 75\%. Those good learning outcomes as a result of the implementation of learning and functional activities as well. So, the application of education and student activities will affect learning outcomes.

Student attitudes such as discipline, responsibility, cooperation, care for the environment and attitudes that show feelings of pleasure, interest, attention, and involvement will also affect student learning outcomes. Attitudes towards teachers and science lessons tend to have an impact on learning outcomes as well. According to Mulyasa (2015) that based on the theory of complete learning, a student said to have finished learning if he can complete, master competencies or achieve learning goals of at least $65 \%$ of all core and essential skills. For class success seen from the number of students who can reach a minimum of $65 \%$, at least $85 \%$ of the total number of students in the class (Sumar, Lamatenggo and ..., 2020). Learning has effectively seen from the results, interest in education, and their attitudes towards the study of Natural Sciences.

So, interest in learning tends to influence learning achievement but does not occur in all children. It saw from the results of the t-test which showed the influence of learning interest on student achievement in Class VII-B, VII-C, and VII-E even though Class VII-A and VII-D did not reveal its effect on learning achievement. The increase in learning achievement is also due to the existence of learning tools that have tested. The validity based on the content format, presentation, structure, and language by validators who declare valid. The practical so that it is appropriate to use in implementing socio-scientific issue comic learning using guided inquiry models to increase interest and learning achievements on earth disaster material. 


\section{Conclusion}

Comics based on socio-scientific issues in the guided inquiry learning model on earth disaster response materials are suitable for use and are able to increase student interest and achievement in science. Socio-scientific comics are suitable to be used to help optimize the guided inquiry learning process because they are in accordance with the learning modalities, interests, abilities, and psychological development of students. SSI comics are feasible in terms of content, construction, presentation and language. Socio-scientific comics tend to be more suitable for children with visual learning styles. Therefore, SSI comics are packaged in guided inquiry learning to optimize learning.

\section{Acknowledgment}

I thank Prof. Erman, M.Pd and Dr. Tjipto Hariyono, M.Si as the supervisor. Then, Dr. Eko Hariyono, M.Pd, Tjipto Prastowo, P.hd, and Tarzan Purnomo, M.Si as examiners. I would like to thank my family and friends at the State University of Surabaya for their support.

\section{References}

Agusman, A. (2017) 'Desain Model Pembelajaran Matematika Yang Mengembangkan Kemampuan Berpikir Kritis', JPM: Jurnal Pendidikan Matematika, 2(2). doi: 10.33474/jpm.v2i2.187.

Ahmadi, N., Arief, Z. A. and Wibowo, S. (2021) 'Pengaruh Metode Pembelajaran Dan Minat Belajar Peserta Didik Terhadap Hasil Belajar Mata Pelajaran Polmas Di Sekolah Polisi Negara Polda Metro Jaya', Jurnal Teknologi Pendidikan, 10(1). doi: 10.32832/tek.pend.v10i1.3995.

Alexander, J. M., Johnson, K. E. and Kelley, K. (2012) 'Longitudinal Analysis Of The Relations Between Opportunities To Learn About Science And The Development Of Interests Related To Science', Science Education, 96(5). doi: 10.1002/sce.21018.

Ambaryani, A. and Airlanda, G. (2017) 'Pengembangan Media Komik Untuk Efektifitas Dan Meningkatkan Hasil Belajar Kognitif Materi Perubahan Lingkungan Fisik', Jurnal Pendidikan Surya Edukasi, 3(1).

Ayesma, P., Kurniawati and Ibrahim, N. (2020) 'Film Sejarah sebagai Media dalam Mengembangkan Literasi di Era Digital', in Prosiding Seminar Nasional Pascasarjana.

Basuki (2014) 'Asesmen Pembelajaran', Bandung: PT. Remaja Rosdakarya Offset.

Bulunuz, M. and Jarrett, O. S. (2010) 'Developing An Interest In Science: Background Experiences Of Preservice Elementary Teachers', International Journal of Environmental and Science Education, 5(1).

Cheung, D. (2018) 'The Key Factors Affecting Students' Individual Interest In School Science Lessons', International Journal of Science Education, 40(1). doi: 10.1080/09500693.2017.1362711.

Chung, B. S. et al. (2016) 'Comic Strips to Accompany Science Museum Exhibits', Journal of Education and Learning, 5(4). doi: 10.5539/jel.v5n4p141.

D., C. P. et al. (1979) 'L. S. Vygotsky: Mind in Society. The Development of Higher Psychological Processes', The American Journal of Psychology, 92(1). doi: 
$10.2307 / 1421493$.

Dasar, K. S., Wurianto, A. B. and Arifin, B. (2015) 'Pengembangan Media Kijank (Komik Indonesia , Jawa , Dan Aksara Jawa) Pembelajaran Bahasa Jawa Berbagai Spekulasi Mengenai Proses Pembelajaran- Fasilitator, Mediator Dan Pembimbing Siswa', pemikiran dan pengembangan SD.

Dwi Waluyanto, H. (2005) 'Komik Sebagai Media Komunikasi Visual Pembelajaran ( Heru Dwi Waluyanto) Komik Sebagai Media Komunikasi Visual Pembelajaran', Jurnal Desain Komunikasi Visual, 7.

Erman, E. and Sari, D. A. P. (2019) 'Science in A Black Box: Can Teachers Address Science from Socio-Scientific Issues?', in Journal of Physics: Conference Series. doi: 10.1088/1742-6596/1417/1/012093.

Farida, U. (2019) 'Urgensi Tahfizh Al-Qur'an Dan Strategi Pembelajarannya Di Pondok Pesantren Subulussalam Demak', Hermeneutik, 11(1). doi: 10.21043/hermeneutik.v11i1.4507.

Haris, A. J. dan A. (2012) Evaluasi Pembelajaran. Yogyakarta: Multi Pressindo.

Johnson, C. C. (2005) 'Making Instruction Relevant to Language Minority Students at the Middle Level', Middle School Journal, 37(2). doi: 10.1080/00940771.2005.11461521.

Johnstone, A. H. (1991) 'Why Is Science Difficult To Learn? Things Are Seldom What They Seem', Journal of Computer Assisted Learning, 7(2). doi: 10.1111/j.13652729.1991.tb00230.x.

Juditha, C. (2014) 'Tingkat Literasi Media Masyarakat Di Wilayah Perbatasan Papua', Journal Communication Spectrum, 3(2).

Keogh, B. and Naylor, S. (1999) 'Concept Cartoons, Teaching And Learning In Science: An Evaluation', International Journal of Science Education, 21(4). doi: 10.1080/095006999290642.

Lee, O. (2004) 'Teacher Change in Beliefs and Practices in Science and Literacy Instruction with English Language Learners', Journal of Research in Science Teaching. doi: 10.1002/tea.10125.

Lee, O. and Fradd, S. H. (1998) 'Science For All, Including Students From Non-EnglishLanguage Backgrounds', Educational Researcher, 27(4). doi: 10.3102/0013189X027004012.

Musfiqon (2012) 'Pengembangan Media Dan Sumber Belajar', Jakarta: PT. Prestasi Pusta Karya, (August).

Nur, M. (2008) Pemotivasian Siswa untuk Belajar. Surabaya: UNESA Pusat Sains dan Matematika Sekolah.

Oberg, A. and Daniels, P. (2013) 'Analysis Of The Effect A Student-Centred Mobile Learning Instructional Method Has On Language Acquisition', Computer Assisted Language Learning, 26(2). doi: 10.1080/09588221.2011.649484.

Olson, J. C. (2008) 'The Comic Strip As A Medium For Promoting Science Literacy', Statistical Field Theor, 53(9).

Osborne, J., Simon, S. and Collins, S. (2003) 'Attitudes Towards Science: A Review Of The Literature And Its Implications', International Journal of Science Education, 25(9). doi: 10.1080/0950069032000032199. 
Pattison, S. A. and Dierking, L. D. (2019) 'Early Childhood Science Interest Development: Variation In Interest Patterns And Parent-Child Interactions Among Low-Income Families', Science Education, 103(2). doi: 10.1002/sce.21486.

Pudjiadi, A. (2005) Sains Teknologi Masyarakat. Bandung: Remaja Rosdakarya.

Ratcliffe, M. and Grace, M. (2003) Science Education For Citizenship, International Journal of Science Education.

Rota, G. and Izquierdo, J. (2003) “Comics" As A Tool For Teaching Biotechnology In Primary Schools', Electronic Journal of Biotechnology. doi: 10.2225/vol6-issue2fulltext-10.

S. Akbar (2013) Instrumen Perangkat Pembelajaran. Bandung: PT Remaja Rosdakarya.

Saidah, N. (2016) 'Seni Rupa Sebagai Stimulasi Visual Dalam Pembelajaran Pai Untuk Anak Usia Sekolah Dasar/Mi', Literasi (Jurnal Ilmu Pendidikan), 4(1). doi: 10.21927/literasi.2013.4(1).33-52.

Slavin, R. E. (2011) Educational Psychology: Theory And Practice 9 Ed. New Jersey: Pearson Education Inc.

Sumar, W. T., Lamatenggo, N. and ... (2020) 'Strategi Guru dalam Implementasi Pembelajaran Abad 21 Melalui Model Pembelajaran Daring untuk Meningkatkan Kompetensi Guru', Jambura Elementary ..., 1(1).

Surna, I. Nyoman \& Pandeirot, O. D. (2014) Psikologi Pendidikan 1. Jakarta: Erlangga.

'Tahap Amalan Pengajaran Berkesan Guru Prinsip Perakaunan Berasaskan Model Slavin (Accounting Principle Teacher's Effective Teaching Practices Based on Slavin's Model)' (2020) Jurnal Pendidikan Malaysia, 45(01). doi: 10.17576/jpen-202045.01-06.

Thiagarajan (1974) Instructional Development for Training Teachers of Exceptional Children, Indiana.

Valenti, S. S. et al. (2016) 'Adolescents' And Emerging Adults' Implicit Attitudes About STEM Careers: "Science Is Not Creative", Science Education International, 40(1).

Weitkamp, E. and Burnet, F. (2007) 'The Chemedian Brings Laughter To The Chemistry Classroom', International Journal of Science Education, 29(15). doi: 10.1080/09500690701222790.

Zeidler, D. L., Herman, B. C. and Sadler, T. D. (2019) 'New Directions In Socioscientific Issues Research', Disciplinary and Interdisciplinary Science Education Research, 1(1). doi: 10.1186/s43031-019-0008-7. 